Bryn Mawr College

Scholarship, Research, and Creative Work at Bryn Mawr

College

Geology Faculty Research and Scholarship

Geology

1982

\title{
Contrast of Metamorphic and Structural Histories Across the Work Channel Lineament, Coast Plutonic Complex, British Columbia
}

Maria Luisa Crawford

Bryn Mawr College, mcrawfor@brynmawr.edu

L. S. Hollister

Let us know how access to this document benefits you.

Follow this and additional works at: http://repository.brynmawr.edu/geo_pubs

Part of the Geology Commons

\section{Custom Citation}

Crawford, M. L., and L. S. Hollister (1982) Contrast of Metamorphic and Structural Histories across the Work Channel Lineament, Coast Plutonic Complex, British Columbia, J. Geophys. Res., 87, no. B5, 3849-3860.

This paper is posted at Scholarship, Research, and Creative Work at Bryn Mawr College. http://repository.brynmawr.edu/geo_pubs/7

For more information, please contact repository@brynmawr.edu. 
CONTRAST OF METAMORPHIC AND STRUCTURAL HISTORIES ACROSS THE WORK CHANNEL LINEAMENT, COAST PLUTONIC COMPLEX, BRITISH COLUMBIA

Maria Luisa Crawford

Department of Geology, Bryn Mawr College, Bryn Mawr, Pennsylvania 19010

Lincoln S. Hollister

Department of Geological and Geophysical Sciences, Princeton University, Princeton, New Jersey 08544

Abstract. A prominent topographic lineament along the western margin of the Coast Plutonic Complex of southeast Alaska and adjacent parts of Britioh Columbia separates terranes of contrasting metamorphic histories where it enters British Columbia near Prince Rupert as the Work Channel lineament. The western terrane preserves a regional medium-high pressure metamorphic facies series, increasing from chlorite grade in the west to kyanite + muscovite migmatite near the 1 ineament. The metamorphic, structural and age relations of the western terrane are consistent with a model of crustal thickening accompanied by westward transport of higher over lower grade metamorphic units during the Jurassic. This terrane was uplifted and cooled by Cretaceous time ( $\sim 85 \mathrm{Ma})$. East of Work Channel lineament, high temperature, relatively low pressure assemblages are overprinted onto high pressure assemblages. The low pressure metamorphic assemblages developed in the Eocene during rapid uplift ( 2 $\mathrm{m} / \mathrm{yr}$ ) of rocks which initially may have been metamorphosed at the same time and along the same PT gradient as those of the western terrane. Structures along the Work Channel lineament suggest vertical motion during uplift of the eastern terrane and after metamorphism of the western terrane. Because the metamorphic discontinuity acrose the lineament is 3-5 kbar at about $700^{\circ}$, the lineament in the Prince Rupert area marks a major crustal break.

Introduction

Good exposures and easy access across the Coast Mountains at the approximate latitude of Prince Rupert, British Columbia $\left(54^{\circ}-55^{\circ} \mathrm{N}\right)$ afford the opportunity to compare and contrast tectonic and thermal events as they relate to one of the major topographic lineaments (Figure 1) in the northeast Pacific. The Work Channel lineament (Figure 2), as the lineament is called in British Columbia, is an extension of the coast Range megal ineament [Brew and Ford, 1978]. In British Columbia, there is a marked difference in tectonic and metamorphic histories across this lineament, which is the subject of the present paper. In southeast Alaska, structural and metamorphic discontinuities are also found that may correlate with those deacribed here for the Work Channel 1 ineament but which occur up to $5 \mathrm{~km}$ to the east of the topographic 1 ineament [Brew

Copyright 1982 by the American Geophysical Union.

Paper number 1B1831.

0148-0227/82/001B-1831\$10.00 and Ford, 1978]. The metamorphic and structural discontinuity has been chosen by Berg et al. [1978] to separate two terranes within the Coast Mountains: the Taku terrane to the west and the Tracy Arm terrane to the east. Based on the description of the two terranes by Berg et al. [1978], we have extended their terminology into British Columbia in the Prince Rupert $1: 250,000$ quadrangle. In British Columbia there is not enough stratigraphic evidence to determine how the Taku and Tracy Arm terranes relate to the Alexander and Wrangelilia terranes to the west or to the Stikine terrane to the east. The Taku and Tracy Arm terranes may represent metamorphosed portions of one or more of the neighboring terranes or they may contain stratigraphic sections that are displaced relative to the other terranes. The Gravina-Nutzot in belt that overlies the boundary between the Taku and Alexander terranes in SE Alaska has not been recognized in the Prince Rupert area.

The differences and similarities in metamorphic and deformational histories on opposite sides of the Work Channel lineament between latitude $54^{\circ}$ and $55^{\circ} \mathrm{N}$ described in this paper are used in an attempt to ascertain, in British Columbia, whether the Taku and Tracy Arm terranes record a shared geologic history. The data serve as a basis for a preliminary model for the thermal and tectonic history of the Coast Plutonic Complex and for the origin of at least the part of the Coast Range megal ineament which extends into British Columbia.

Our data came from the following sources:

Structure. The reconaisance map at a scale of $1: 250,000$ and description by Hutchison [1967, 1971] give the regional framework within which Crawford has mapped at 1:50,000 the Tsimpsean Peninsula and nearby islands to the west of Work Channel lineament (Figure, 2) and Hollister has mapped at the same scale the area in the vicinity of Khtada Lake east of Work Channel lineament (Figure 2). Structural data relevant to the present paper are summarized in Figures 2 and 3.

Petrology. Pub1ished detailed petrologic studies [Crawford et al., 1979; Selverstone and Holliater, 1980] at localities 1 and 2 (Figure 2) provide the pressure-temperature conditions of metamorphism (Figures 4 and 5) which form a basis of reference for petrographic information from samples collected el sewhere in the area of Fig. 2 .

Age. $\mathrm{K}-\mathrm{Ar}$ dates on biotite and hornblende published by Hutchison [1970] provide the framework for additional $\mathrm{K}-\mathrm{Ar}$ dates and fissiontrack dates by Harrison et al. [1979], a Rb-Sr whole rock isochron by Armstrong and Runkle 


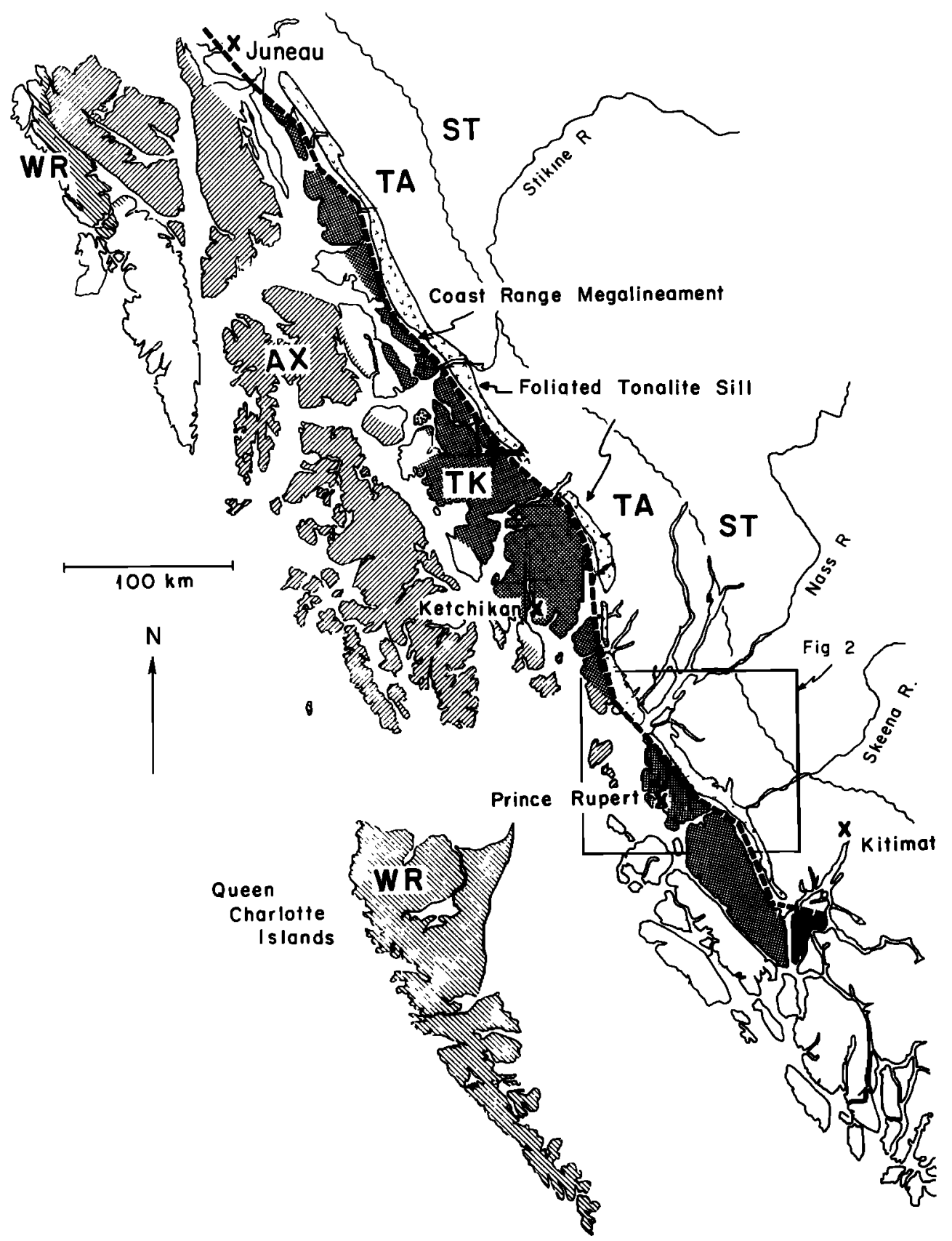

Fig. 1. Distribution of terranes [after Berg et al., 1978] in southeast Alaska and adjoining portions of British Columbia. ST, Stikine terrane; TA, Tracy Arm terrane (boundary between Stikine and Tracy Arm terranes shown as irregular line); TK, Taku terrane; AX, Alexander terrane; WR, Wrangellia. Other terranes and the Gravina-Nutzot in belt are not labeled. Heavy dashed line, trace of Coast Range Megalineament. Foliated tonalite sill occurs along most of the eastern side of megalineament [Brew and Ford, 1978] and includes the Quottoon Pluton within the area of Figure 2.

[1979] from the Quottoon Pluton west of Kitimat (Figure 1), and zircon ages for the Central Gneiss Complex (G. Woodsworth and W. Loveridge, personal communication, 1981) and the Quottoon P1 uton [Armstrong and Runkle, 1979]. Dates from both sides of the Coast Range megal ineament in the Ketchikan quadrangle by Smith et a1. [1979] and Smith and Diggles [1981] define a pattern that we extrapolate into British Columbia and that is consistent with dates obtained in British Columbia.
Age Relations

No fossils have been found in the Central Gneiss Complex east of the Work Channel lineament. West of the lineament, poorly preserved crinoids in cobbles of 1 imestone from the north shore of Digby Island (Figure 2) suggest only that a portion of the section is younger than mid to late Paleozoic or early Mesozoic in age. Fossils found on an island off the northwest corner of Digby Island and on several islands 


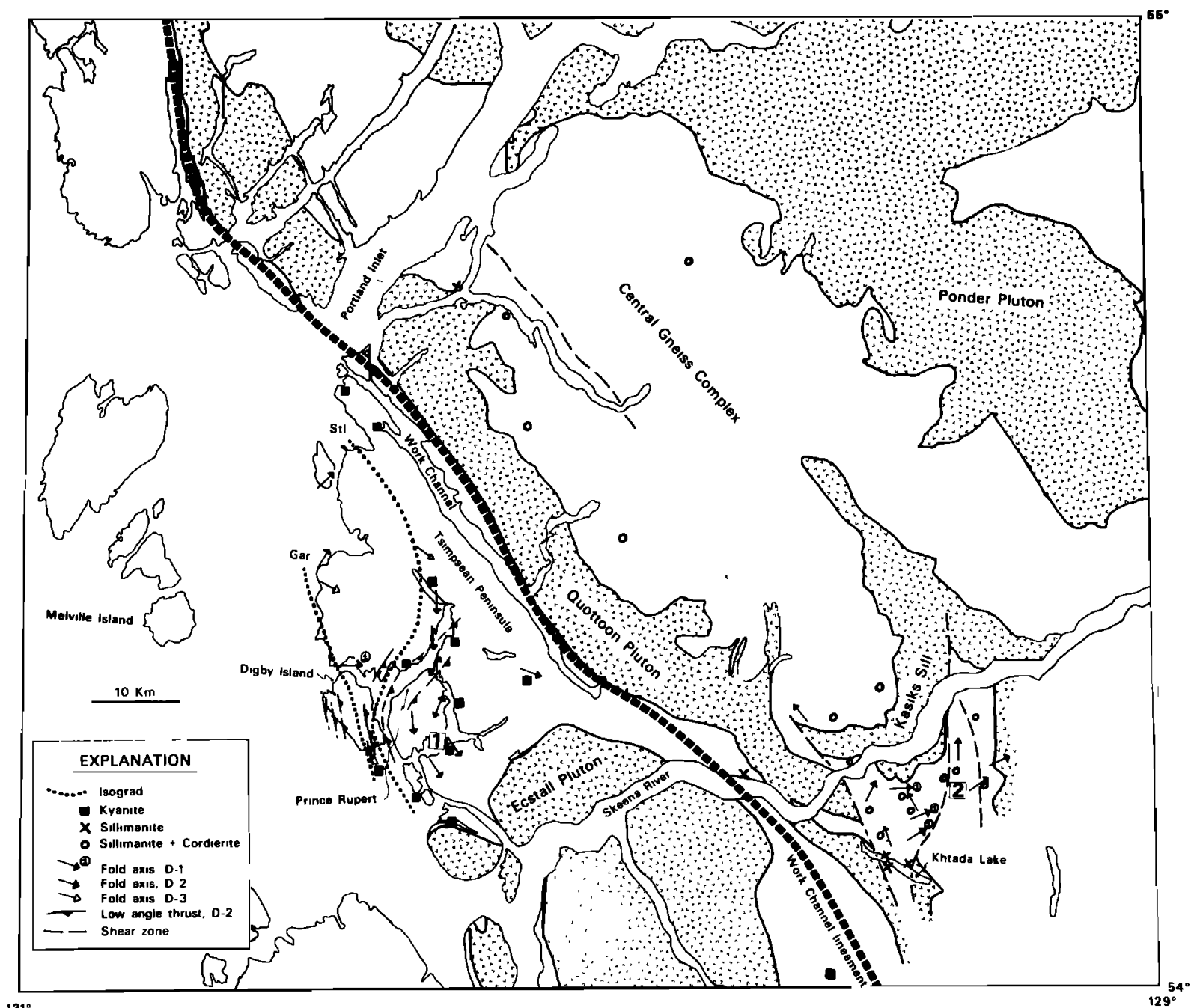

Fig. 2. Distribution of large intrusive bodies (patterned areas) within Prince Rupert-Skeena Map area slightly modified from Hutchison [1971]. Detailed petrology at locality 1 given by Crawford et a1. [1979] and Figure 4; at locality 2 given by Selverstone and Hollister [1980] and Figure 5. Other petrologic data, and the structural data shown, are from mapping and reconnaissance by Crawford and her students (to west of Work Channel lineament, heavy dashed $1 \mathrm{ine}$ ) and Hollister and his students (to east of lineament) except the kyanite locality at south edge of sheet which is based on an observation by $G$. Woodsworth. Gar, garnet isograd; St1, staurolite isograd; other symbols defined in explanation.

north of Melville Island are tentatively assigned upper Paleozoic to upper Triassic ages (G. Woodsworth and M. Orchard, personal communication, 1981).

As first pointed out by Hutchison [1970], the Work Channel lineament defines a boundary between regions of differing $\mathrm{K}$-Ar dates. To the east, virtually all $\mathrm{K}-\mathrm{Ar}$ biotite dates on plutonic rocks and gneisses are between 41 and $49 \mathrm{Ma}$; to the west they are between 64 and $77 \mathrm{Ma}$. Smith et al. [1979] and Smith and Diggles [1981], with more complete coverage over a wider area to the west of the Coast Range megalineament in southeast Alaska at the approximate latitude of Ketchikan, point out that as the lineament is approached from the west, $\mathrm{K}$-Ar ages on hornblende in plutonic rocks progressively decrease from 85 Ma to about $55 \mathrm{Ma}$ at the lineament. They suggested this age progression may have resulted from the reheating of the western terrane by the approximate $50 \mathrm{Ma}$ thermal event of the eastern terrane. On the other hand, if the uplift of the western terrane were hinged about an approximate NNW trending axis wegt of Ketchikan, slower and later cooling through the argon retention temperatures of rocks closer to the eastern border could result in the observed decrease in ages from west to east. The oldest $\mathrm{K} / \mathrm{Ar}$ date reported by Smith and Diggles [1981] for rocks in the Taku terrane is $112 \mathrm{Ma}$ (hornblende on an epidotebearing pluton near Retchikan).

The largest pluton in the Prince Rupert area is the primary epidote-bearing Ecstall pluton. The absolute age of the Ecstall Pluton is suggested as Jurassic by a $\mathrm{Rb}-\mathrm{Sr}$ whole rock isochron [Armstrong and Runkle, 1979]; B. Ryan and R.L. Armstrong (personal communication, 1981) have obtained a $\mathrm{Pb}-\mathrm{U}$ date of 181 Ma for this pluton, confirming a Jurassic age. Mineral isochrons from undeformed pegmatite cutting the pluton give 


\section{West of Lineament}
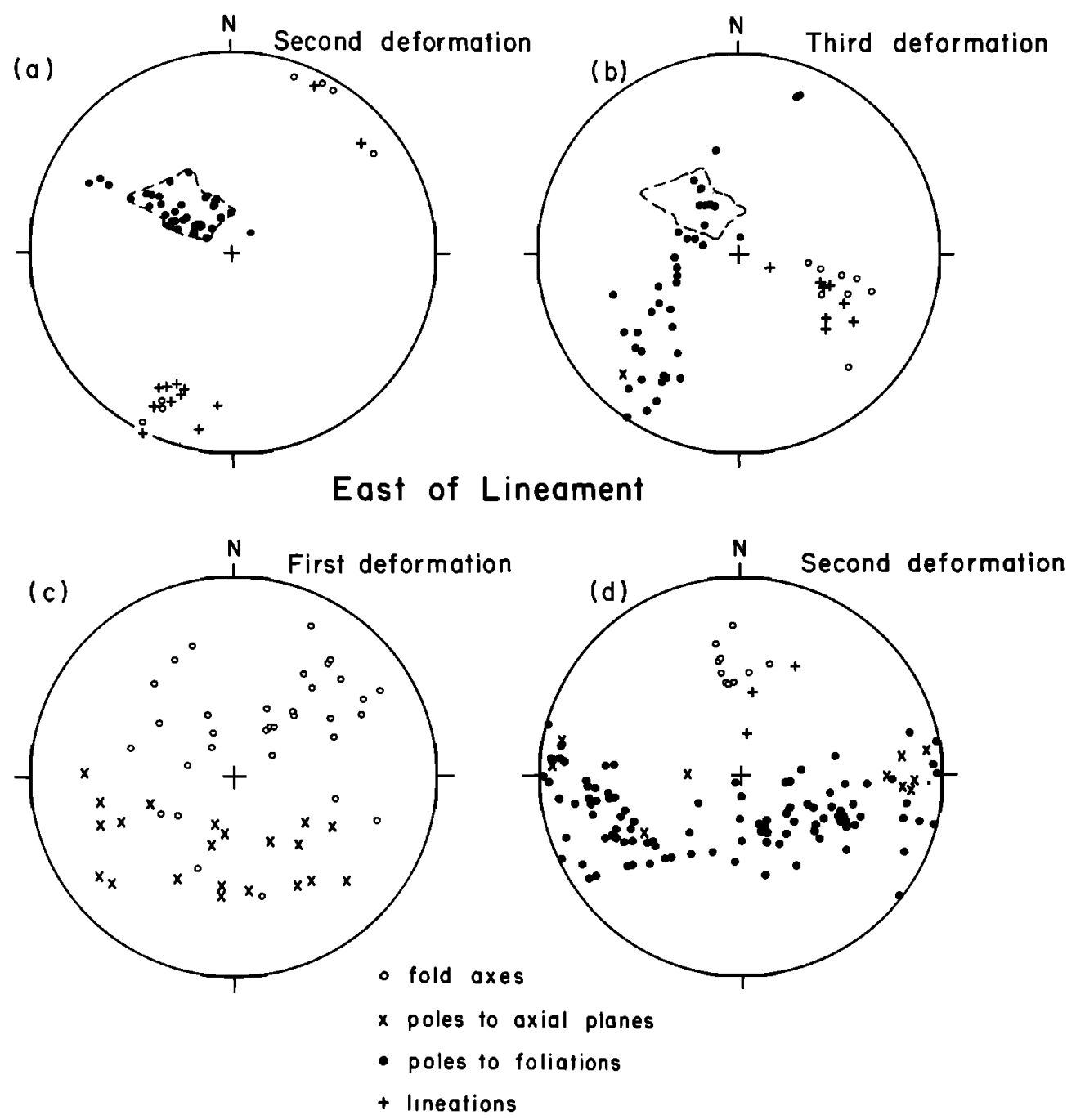

Fig. 3. Stereographic projections (southern hemisphere) of structural elements.

(a) Data for DW-2 (second deformation, west of lineament) for one small area near Prince Rupert, unaffected by DW-3. Shows generally SSW trending axes and 1 ineations associated with northwest verging isoclinal folds. (b) Shows DW-2 foliations rotated and folded about moderate to steeply SE plunging axes of DW- 3 in an area close to the 1 ineament. Field outlined on Figure $3 b$ same as that of Figure 3a. (c) Fold axes and poles to axial planes of DE-l which have been rotated around axes which would fall in cluster of north-plunging fold axes shown in Figure 3d. (d) Shows rotation of foliations developed by $D E-1$, and the generally upright axial planes of north plunging DE-2 folds from $2 \mathrm{~km}$ north of locality 2, Figure 2 .

$79 \mathrm{Ma}$ ages [Armstrong and Runkle, 1979]. A detailed study of fission track dates [Harrison et al., 1979] for this pluton suggests reheating, probably by the nearby younger Quottoon Pluton. This interpretation is consistent with that of Snith et al. [1979] for the $\backsim 50$ Ma reheating event in southeast Alaska which was attributed to intrusion of granodiorites similar to the Ponder Pluton (Figure 2) but which, in the Ketchikan area, 1 ie closer to the megalineament than does the Ponder Pluton in British Columbia.

$\mathrm{K}$-Ar ages for biotite from the Ponder P1uton fall between 41 and $49 \mathrm{Ma}$ and thus agree with the 43-48 Ma biotite $\mathrm{K} / \mathrm{Ar}$ ages reported by Smith and
Diggles [1981] for all the rocks they analyzed east of the megalineament east of Ketchikan. They report that hornblende ages are uniformly 7 Ma older. In contrast to the Quottoon and related plutons within the Central Gneiss Complex, Magaritz and Taylor [1976] suggest the Ponder Pluton along the eastern margin of the Central Gneiss Complex is a shallow level intrusion. They base this conclusion on the stable isotope compositions of those igneous bodies. Their model is consistent with the interpretation of differing levels of intrusion by Hutchison [1970] based on the style of intrusion of the plutons and the observation that the eastern boundary of 


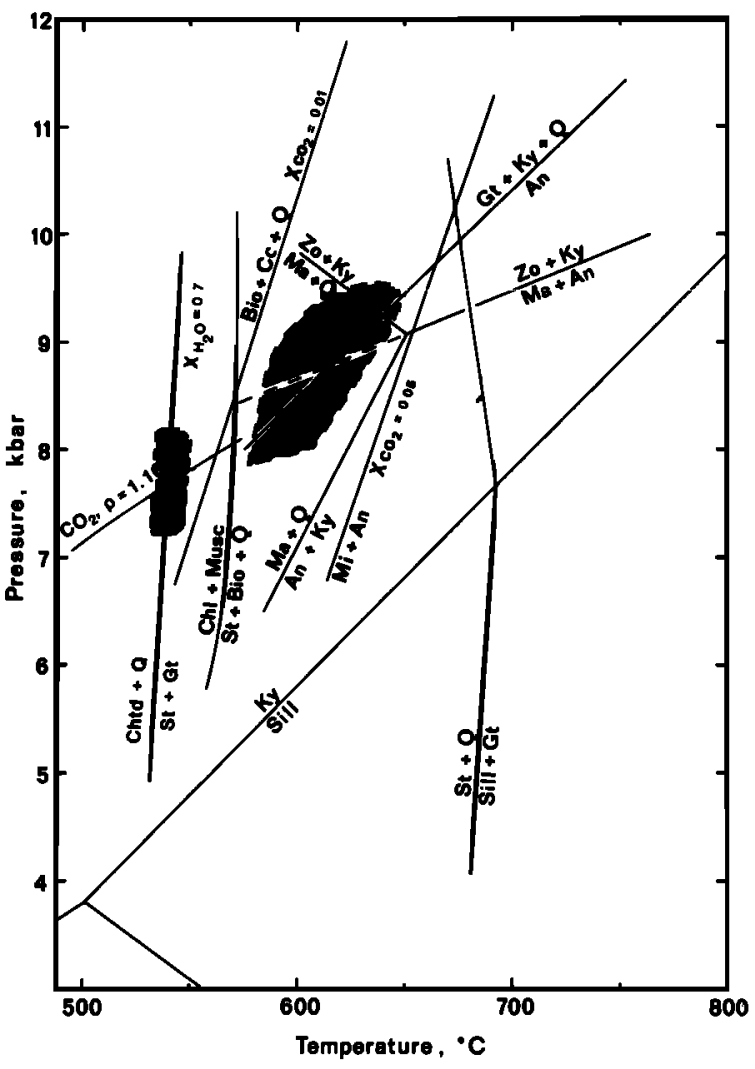

Fig. 4. Phase equilibria used to define pressure-temperature conditions (patterned area at about $9 \mathrm{kbar}$ and $630^{\circ} \mathrm{C}$ ) at locality 1

(Figure 2), and PT conditions at the staurolite isograd (patterned area at about $7.5 \mathrm{kbar}$ and $550^{\circ} \mathrm{C}$ ) at the south tip of Digby Island (Figure 2). Details of the phase equilibria pertaining to locality 1 are given by Crawford et al. [1979] except that the slope of the magarite $(\mathrm{Ma})+$ quartz $(\mathrm{Q})=$ zoisite $(\mathrm{ZO})$ + kyanite ( Ky) curve has been changed to be consistent with the thermodynamic data for these phases [Perkins et al., 1980], and the appropriate curve for the equilibria between garnet (Gt), quartz ( $Q$ ), plagioclase (An), and kyanite according to Ghent et al. [1979] has been added. The garnet has 0.107 mole fraction grossular component and the plagioclase has 0.227 mole fraction anorthite component. For the PT conditions at the staurolite isograd, the curve chloritoid (Chtd) + quartz $(Q)=$ staurolite (St) + garnet (Gt) is from Ganguly (1969), calculated at $P\left(H_{0} 0\right)=0.7$ $\mathrm{P}$ (total). The isochgre for pure $\mathrm{CO}_{2}$ wth a density of $1.16 \mathrm{~g} / \mathrm{cm}^{3}$ (the densest in rocks at the south end of Digby Island) gives a minimum pressure for metamorphism at $550^{\circ} \mathrm{C}$ (see Crawford [1981] for discussion of the use of fluid isochores in the interpretation of metamorphic rocks). Other symbols: Ch1 (chlorite), Musc (muscovite), Bio (biotite), Cc (calcite), Mi (microcline), sill (sillimanite).

the Ponder Pluton is marked by a narrow contact metamorphic aureole containing andalusite.

$\mathrm{Pb}-\mathrm{U}$ dates, in addition to the $181 \mathrm{Ma}$ age in the Ecstall Pluton, have been obtained on zircons at several localities on both sides of the lineament. In southeast Alaska, a 131-137 Ma age was reported on the west side of the 1 ineament from the same pluton near Retchikan as the $112 \mathrm{Ma}$ $\mathrm{K}-\mathrm{Ar}$ hornblende age [Smith et a1., 1979]. Smith and Diggles [1981] report that other plutons west of the lineament and north of Ketchikan give 90 $\mathrm{Ma} \mathrm{Pb}-\mathrm{U}$ dates, and they suggest these plutons were intruded after or during the waning phases of regional metamorphism. Migmatite in the Central Gneiss Complex along the Boca de Quadra inlet east of the 1 ineament yielded discordant 117-140 Ma Pb-U ages [Smith et a1., 1979]. In British Columbia, discordant ages as old as 171 Ma have been obtained from the Central Gneiss Complex (Figure 2), but several $\mathrm{Pb}-\mathrm{U}$ dates from the Central Gneiss Complex are nearly concordant and range between 65 and $85 \mathrm{Ma} \mathrm{(G.} \mathrm{Woodsworth} \mathrm{and}$ W. Loveridge, personal communication, 1981). Armstrong and Runkle [1979] report a Pb-U date of 58-60 Ma for the Quottoon Pluton from south of the area shown on Figure 2 and $a \mathrm{Rb}-\mathrm{Sr}$ whole-rock isochron of $51 \pm 2 \mathrm{Ma}$. J. Arth (personal cormunication, 1981) reports two $\mathrm{Pb}-\mathrm{U}$ dates of $58 \mathrm{Ma}$ from plutonic rocks correlative with the Quottoon Pluton just east of the lineament in the Ketchikan area.

A preliminary interpretation of these ages and the field relations described in the next section suggest that at least one thermal event, probably in the Jurassic but no younger than $85 \mathrm{Ma}$, affected both terranes. This thermal event was responsible for the development of a medium to high pressure regional metamorphic complex on the west and possibly also the east, as discussed below. A major point also discussed in the next sections is that the intrusion of the Ecstall Pluton accompanied the regional metamorphism to the west of the lineament. These rocks were uplifted and cooled below the argon retention temperature of biotite $\left(\sim 250^{\circ} \mathrm{C}\right)$ by $\backsim 85 \mathrm{Ma}$. East of the lineament, the 58-60 Ma Quottoon Pluton began its cooling history at $>51 \mathrm{Ma}$ ( $\mathrm{Rb}-\mathrm{Sr}$ whole rock isochron); the 41-49 Ma K-Ar ages of the plutons and gneisses suggest cooling through the $\mathrm{K}-\mathrm{Ar}$ blocking temperatures during the Eocene, accompanied by emplacement of shallowlevel plutons like the Ponder.

\section{Structure}

The Work Channel lineament separates rocks that show different structural styles and preserve different types of structural data. West of the lineament, in generally lower grade metamorphic rocks, several episodes of deformation that generated penetrative cleavages and easterly and southeasterly dipping thrust faults and shear zones can be documented. East of the lineament metamorphic conditions were everywhere close to or hotter than those required for partial melting [Lappin and Hollister, 1980; Kenah, 1979], resulting in gneisses that may not preserve early deformation stages and obliterating evidence of overprinting of older structural elements by younger ones. On both sides of the lineament, intrusion of plutons has disrupted pre-plutonic structures and generated new structures.

Three distinct deformational events can be identified west of the Work Channel lineament (Figure 2). The oldest ( DW-1), preserved along the western and southwestern shores of Tsimpsean Peninsula, consists of recumbent to upright folds 


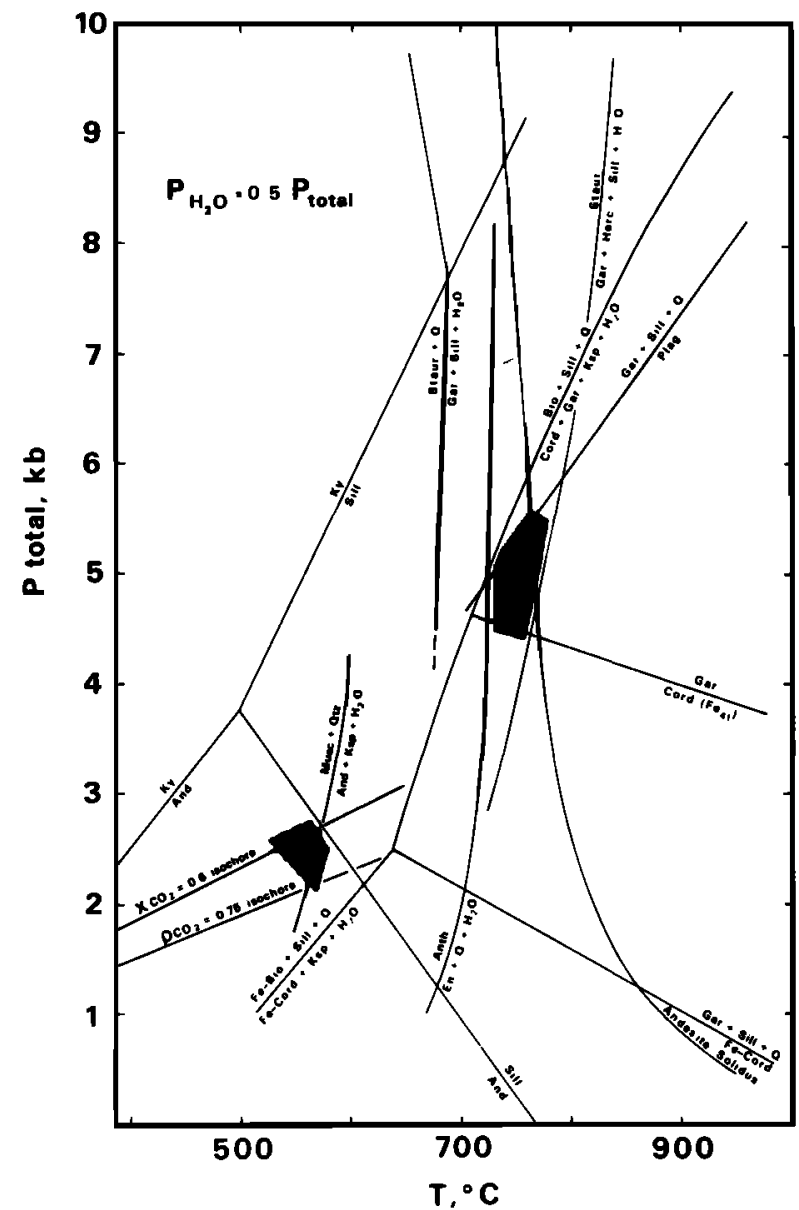

Fig. 5. Phase equilibria used to define pressure-temperature conditions (the patterned area at about $5 \mathrm{kbar}$ and $750^{\circ} \mathrm{C}$ ), at locality 2 (Figure 2) and late stage pressure-temperature conditions (the patterned area at about $2.3 \mathrm{kbar}$ and $575^{\circ} \mathrm{C}$ ) defined by crosscutting veins with the assemblage muscovite (Musc), quartz (Qtz), andalusite (And), sillimanite (Sil1), and potassium feldspar (Ksp). No dates have been obtained on these veins, but they are tentatively correlated with the thermal event associated with the Ponder Pluton. The curve labeled ' $\mathrm{x}\left(\mathrm{CO}_{2}\right)=0.6$ ' isochore is the PT curve for low density $\mathrm{CO}_{2}-$ $\mathrm{H}_{2} \mathrm{O}$ fluids containing 0.6 mole fraction $\mathrm{CO}_{2}{ }^{2}$ which were entrapped in rocks east of the lineament at the time when the andalusite-bearing veins were formed; an explanation for the use of fluid isochores pertaining to uplift of metamorphic terranes is given by Hollister et al.

[1979]. Details of the use of the phase equilibria curves pertaining to locality 2 are given by Selverstone and Hollister [1980]. Other abbreviations: Ky (kyanite), Bio (biotite), Staur (staurolite), Gar (garnet), Cord (cordierite), Herc (hercynite), Plag (plagioclase).

with axial planes which dip NE and fold axes plunging 20 ESE. Regional foliation associated with these folds is not always well developed; pebbles were flattened and elongated by this deformation. The second deformation (DW-2) is characterized in lower grade rocks by tight isoclinal folds with an axial plane cleavage dipping generally southeast to east and fold axes plunging gently south and southwest or approximately horizontal (Figure $3 a$ ). The cleavage associated with this deformation cuts across both $1 \mathrm{imbs}$ of mesoscopic DW-1 folds. This cleavage is the dominant fabric element in the rocks west of the lineament, and porphyroblast textures in the schists suggest that the metamorphism was synchronous with this second deformation event. The DW-2 event juxtaposed three distinct stratigraphic packages. The structurally uppermost unit is a kilometer scale nappe cored by migmatitic schists and gneisses that lies north of the Ecstall Pluton. Under this, amphibolite grade metagraywackes and amphibolites, which underlie the city of Prince Rupert and central Tsimpsean

T Peninsula, are increasingly deformed westward. They apparently overlie the third unit, consisting of lower grade carbonaceous schists and felsic metavolcanics of Digby Island and western Tsimpsean Peninsula, along a major thrust located just west of Prince Rupert. Near the Ecstall Pluton, the structures of the second deformational event can be subdivided into an earlier and a later set. The later set, which overprints the earlier ones, includes folds which refold the earlier second deformation structures and shallowly to moderately east-dipping thrusts with east-over-west transport directions. These structures wrap around the western and northern edges of the pluton. The structural style suggests that the deformation was continuous from a higher temperature plastic to a lower temperature more brittle regime. A similar change in deformation style from more plastic to brittle al so characterizes the DW-2 structures as they are traced from the high grade metamorphic rocks in the east to the low grade rocks in the west. The DW-2 deformation also apparently accompanied the emplacement of the Ecstall Pluton into its present position. The margin of the pluton is involved in the NW directed thrusting, and much of the margin of the pluton is strongly foliated. However, lack of metamorphic recrystallization, undeformed cross cutting pegmatites, and a marked decrease in deformation from the narrow marginal zone toward the center of the pluton suggests that it was not completely solidified at this time. Significant flattening, accompanied by boudinage on scales up to several hundred meters, al so characterized this deformation. West of the Ecstall pluton, dacitic dikes are intruded along zones of more intense secondstage deformation. DW-2 is thought to represent a Jurassic event based on the $181 \mathrm{Ma}$ age of the Ecstall pluton, the $79 \mathrm{Ma}$ age of undeformed later pegmatites and the $85 \mathrm{Ma} \mathrm{K} / \mathrm{Ar}$ cooling dates on biotite.

The third deformation ( DW-3) is locally marked on the western shores of Tsimpsean Peninsula by warping of earlier foliation planes and development of crenulation cleavage. These effects increase in intensity toward the Work Channel lineament, where earlier folds are compressed and rotated to plunge steeply SE (Figure 3b) or NW; the trends of the axes are approximately paral$1 \mathrm{el}$, or at a small angle, to the strike of the lineament. The foliations and fold axes become vertical close to the lineament. Mylonites with well-developed vertical 1 ineations and locally developed horizontal extension fractures 1 ie along the 1 ineament near or along the western border of the Quottoon Pluton (Figure 2). DW-3 
is probably related to intrusion of the Quottoon P1uton and/or the uplift event (see below) of the Central Geiss Complex.

In the eastern terrane, the earliest recognized deformation ( $D E-1$ ) is largely obscured by the 1 ater deformations and plutonism; the possibility of an even earlier deformation cannot be ruled out. The earliest fold axes may have been east-west. Some ENE to ESE axes were measured between Kht ada Lake and Skeena River, between Kasiks Sill and Ponder Pluton (Figure 2; D. Kraus, unpublished notes, 1977), and were interpreted from map patterns. These structures may correlate with the DW-2 isoc1inal folds and nappe west of the 1 ineament. Both DE- 1 and DW-2 folds have well-developed axial plane foliations. In addition, the large DW-2 nappe and the $D E-1$ folds are similar in size; however, the structures show opposite directions of overturning: West of the lineament the structures are overturned to the northwest, but east of the lineament they are overturned to the south. Other apparently early axes were rotated by folding during the second deformation (DE-2). poles to axial planes of these rotated folds define a girdle (Figure $3 \mathrm{c}$ ) with an axis of rotation approximately parallel to fold axes of DE-2 (Figure 3d). The second-generation folds have near vertical axial planes (Figure 3d), and their axes typically plunge gently to moderately $\left(20^{\circ}-60^{\circ}\right)$ to the north; the second folding al so folds the foliation. Locally, second generation axes have other directions of plunge, for example to the northwest near the shear zone cutting the Quottoon Pluton (Figure 2).

The final deformational event consists of shear zones (Figure 2) which, where it could be determined, are approximately parallel to the axial planes of the nearby second deformation folds. These zones cut the Kasiks and Quottoon plutons (Figure 2). Within the shear zones, which have widths from a few centimeters to hundreds of meters, a flow foliation is developed; in places, dikes of tonalite composition occur along them.

Kenah [1979] studied the portion of the Quottoon Pluton west of Khtada Lake (Figure 2) and showed that it contains primary crystallization features, was not metamorphosed, and was intruded after DE-1. Foliations there are generally steep and variable in direction, and lineations are near vertical. Mineral textures within the pluton show euhedral zoned growth on anhedral cores. These data are consistent with a model of diapiric intrusion of crystal-1iquid mush. Elsewhere in the Quottoon Pluton, foliation is generally well developed. At the western margin it is near vertical and strikes parallel to the margin. Foliations along the eastern margin are more variable in strike and dip, ranging from vertical and parallel to the long axis of the pluton to northwest striking and steeply dipping $\left(\sim 60^{\circ}\right)$ to the northeast. This range of attitudes is similar to those of the foliations in the gneiss along the eastern margin of the pluton. These are controlled by $D E-2$, and therefore we attribute the control of attitudes in the Quottoon Pluton to DE-2. The conformity of attitudes of foliation along the western margin of the Quottoon to those attributed to DW-3 allows the inference that $\mathrm{DW}-3$ and $\mathrm{DE}-2$ were contemporaneous and occurred during the early Eocene based on the 58-60 Ma age of the quottoon.

The last stages of metamorphism east of the 1 ineament, which resulted in partial melting of substantial portions of the Central Gneiss Complex, were synchronous or after DE-2. In a few places, lineations of sillimanite needles subparallel to $\mathrm{DE}-2$ fold axes were observed; lineations of hornblende crystals in tonalite along the shear zones are also subparallel to DE-2 fold axes. However, the leucozome of the migmatite does not have a fabric and is locally concentrated in $\mathrm{DE}-2$ fold noses.

In the eastern terrane, therefore, only two diecrete deformational events are structurally recognized: (1) development of $\mathrm{EW} \mathrm{DE}-1$ fold axes and (2) generally synchronous folding ( $D E-2)$, metamorphism, intrusion of the Quottoon pluton and Kasiks Sill, and shearing. These events may have occurred over a substantial period of time if the rocks remained near the temperature for partial melting. The final major thermal event in the area was the emplacement of the Ponder Pluton at 41-49 Ma.

\section{Met amorphism}

Metamorphism increases in intensity from west to east across the western terrane, ranging from the biotite to the kyanite zone (note garnet and staurolite isograds on Figure 2). In the high grade rocks, at locality 1 (Figure 2), peak metamorphic conditions were at least 9 kbar and $630^{\circ} \mathrm{C}$ [Crawford et al., 1979] (Figure 4). Kyanite-bearing migmatites are formed closer to Work Channel lineament, presumably reflecting slightly higher temperatures at a high pressure. Some of the migmatitic rocks of the central part of Tsimpsean Peninsula (Figure 2) are affected by DW-2 structures; others, particularly those right along the 1 ineament, are later and are clearly associated with $\mathrm{DW}-3$. The widespread occurrence of kyanite in rocks of appropriate composition 1ying immediately west of the lineament (Figure 2) suggests that the se metamorphic conditions may be extended northwestward along the west aide of the 1 ineament. Pressures at the staurolite isograd at the south end of Digby Island (Figure 2), inferred from the mineral assemblage and fluid inclugion measurements, were at least 7.5 kbar at $550^{\circ} \mathrm{C}$ (Figure 4). No high pressure glaucophane or lawsonite-bearing mineral assemblages were found in the lower grade rocks. These data imply that the rocks were metamorphosed along a geothermal gradient no greater than $25^{\circ} \mathrm{c} / \mathrm{km}$.

The Ecstal1 Pluton contains 2-6 modal percent euhedral epidote with rare-earth enriched cores which, on textural criteria, crystallized early from the melt, along with hornblende and biotite. Layers containing cumulate epidote support the interpretation that epidote is a primary igneous mineral in this pluton. Experiments by Naney [1977] on a granodiorite composition show that at 8 kbar epidote can be a primary phase crystallizing from felsic melt compositions. The intersection of the stability curves for epidote [e.g., Liou, 1973] with curves for 1iquidus phases in tonalite melts [e.g., Wyllie, 1977] are $6 \mathrm{kbar}$ or higher. Based on these data, we conclude that the Ecstall pluton crystallized at 
high pressure during the metamorphism of the western terrane.

The structural data suggest that higher grade rocks presently overlie lower grade ones, implying structural inversion of the section. This is based on the easterly to southeasterly dip of foliations and thrust planes and the westerly vergence of the mesoscopic folds. Rocks originally metamorphosed successively deeper in the crust are exposed in the structurally higher slices to the southeast toward the contact of Ecstall Pluton and to the east toward the lineament. Metamorphic minerals grow parallel to and across the DW-2 regional foliation. Some are clearly syntectonic, as these are rotated by this deformation. The minerals are al so stretched in a manner analogous to the stretching which produced boudinage in the more competent layers. Thus, the second deformation (DW-2) accompanied the metamorphism and emplaced the higher grade rocks over the lower grade ones. This implies that tectonic disruption of the deeper crust, emplacing higher over lower temperature rocks, may, at least in part, be responsible for the present pattern of metamorphic isograds. The $\mathrm{K}-\mathrm{Ar}$ dates from the area, and from southeastern Alaska, near Ketchikan, suggest that this metamorphism was completed prior to $85 \mathrm{Ma}$. Other than effects on the isotope systems, no metamorphic features have yet been identified away from the lineament in the western terrane that can be unequivocally attributed to the later ( $\sim 50 \mathrm{Ma}$ ) reheating event.

In the eastern terrane, metamorphic mineral assemblages and textures strongly suggest that the rocks contain evidence of metamorphic reactions arrested during a natural quenching process. Phase assemblages characteristic of high pressures and temperatures are partially replaced by assemblages indicating lower pressures. Although an interpretation of isobaric temperature increase could account for some of the textures, pressure decrease without significant temperature change is the overall most reasonable interpretation. After an initial rapid, nearly isothermal, pressure decrease, the temperature must have dropped sufficiently rapidly to preserve the high pressure assemblage relics and the low pressure reaction products.

Several textural examples supporting this conclusion have been published elsewhere [Hollister, 1977, 1982; Selverstone and Hollister, 1980]. Holligter [1977, Figure 3] illustrated and described the occurrence of kyanite inclusions in garnet in samples where the $\mathrm{Al}_{2} \mathrm{SiO}_{5}$ polymorph in the matrix is sillimanite, and bccurrences of cordierite-bearing low pressure assemblages which replaced the higher pressure garnet + sillimanite + quartz assemblages. The position of the reaction curve in PT space for the latter occurrences was calculated by Selverstone and Hollister [1980], following the procedure of Holdaway and Lee [1977], and is shown in Figure 5. Figure 5 also shows the position of the curve for the observed reaction sillimanite + garnet + quartz = plagioclase [Hollister, 1977] calculated following the procedure of Ghent et al. [1979] for several localities in the eastern terrane [Selverstone and Hollister, 1980]. Symplectites of hypersthene replacing garnet al so suggest a pressure decrease [Hollister, 1982; Perkins and
Newton, 1981] at a temperature above that for the reaction anthophyllite = enstatite + quartz $+\mathrm{H}_{0} \mathrm{O}$ which was estimated to be $725^{\circ} \mathrm{C}$ at locality 2 (Figure 2) by Selverstone and Holl ister [1980].

A relatively low pressure and temperature occurring late in the metamorphic history of the area is suggested by the occurrence of late andalusite-bearing veins which crosscut the fabric of the sillimanite gneiss. The assemblage in the veins is andalusite-fibrolitemuscovite-orthocl ase-quartz-p1agioclase, which, assuming equilibrium crystallization, constrains the PT conditions of formation of the veins to lie along the muscovite + quartz = potasssium feldspar + andalusite (or sillimanite) reaction curve for the appropriate $P\left(\mathrm{H}_{2} \mathrm{O}\right)$. The position of the curve shown in Figure 3 , for $P\left(H_{2} O\right)=$ $0.5 \mathrm{P}($ total $)$, was chosen because it interrsects the isochore for low density $\mathrm{CO}_{2}$ inclusions $(p=0.75)$ which occur in these veins and the isochore for late secondary $\mathrm{CO}_{2}+\mathrm{H}_{2} \mathrm{O}$ fluid inclusions with $X\left(\mathrm{CO}_{2}\right)=0.6$ which are common in the Central Gneiss Complex, and it is near the sillimanite boundary, as suggested by the presence of fibrolite in the veins.

These observations taken together strongly suggest that $P$ was decreasing when the reactions occurred. If a model of monotonic decrease of pressure is invoked to account for all occurrences, without additional heat input to the system,

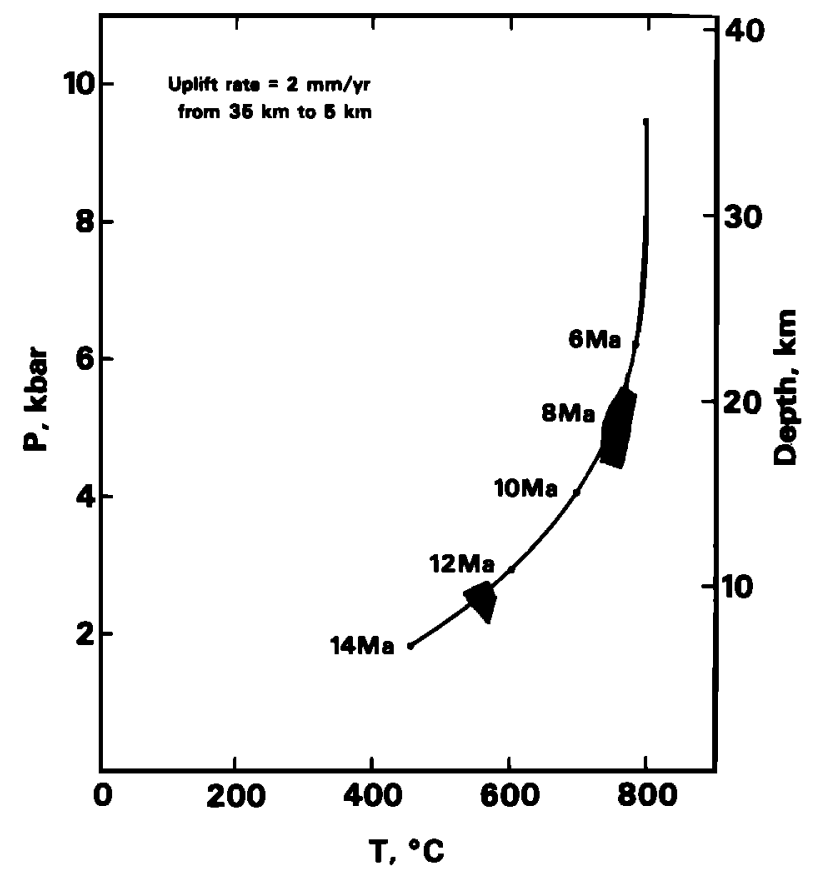

Fig. 6. Uplift curve taken from Figure 9 of Albarède (1976] for a uniform rate of uplift of 2 $\mathrm{mm} / \mathrm{yr}$. PT points are shown at time intervals beginning from the initiation of uplift from starting conditions at $35 \mathrm{~km}, 800^{\circ} \mathrm{C}$. Patterned areas are the two $P T$ regions shown in Figure 5. For the rocks in this model, uplift terminates at $5 \mathrm{~km}$; the cooling curve therefore continues asymptotically to temperatures on the steady state geothermal gradient at $5 \mathrm{~km}$. See Hollister [1982] for further details pertaining to this figure. 
then the decompression path would begin in the kyanite field at about $10 \mathrm{kbar}$, pass through the PT region drawn at about 5 kbar (Figure 5), and continue, as temperature decreased, through the estimated PT conditions of the late andalusitebearing veins at about $2.5 \mathrm{kbar}$ and $550^{\circ} \mathrm{C}$.

The uplift model to interpret the metamorphic history of the eastern terrane is summarized in Figure 6. This model, which applies specifically to rocks near Khtada Lake, has been described in detail elsewhere [Hollister, 1979, 1982; Ho11ister and Sherwood, 1980]; it is based on calculations for a locality in the Massif Central, France, which has petrologic evidence for a similar uplift history [Albarède, 1976]. The rocks near Khtada Lake were at a high $P$ and $T$ initially and were later subjected to rapid lowering of pressure (uplift) with the PT-time path as illustrated. About $15 \mathrm{~km}$ of uplift is implied at a rate of $\sim 2 \mathrm{~mm} / \mathrm{yr}$ between $\sim 55 \mathrm{Ma}$ and $\checkmark 47 \mathrm{Ma}$ (rocks at 20 and $5 \mathrm{~km}$, respectively). This uplift terminated with the intrusion of the shallow-level emplacement of the Ponder Pluton which we tentatively correlate with the thermal event associated with the emplacement of the late andalusite-bearing veins as well as other postmetamorphic crosscutting aplite, pegmatite, and granodiorite dikes common throughout the Central Gneiss Complex. In the model, the Eocene uplift terminated when the rocks presently exposed were at $5 \mathrm{~km}$ depth; this allows for later, Miocene uplift of the Coast Mountains [Parriah, 1980].

It must be emphasized that no evidence for uplift at this rate at this time is present west of the Work Channel lineament.

A second simple model could account for the petrologic data from the Central Gneiss Complex. A PT path could begin in the kyanite field at lower $P$ and $T$ (for example, $5.5 \mathrm{kbar}$ and $500^{\circ} \mathrm{C}$ ), pass more or less isobarically to about $800^{\circ} \mathrm{C}$ as a result of input of heat from intrusion of tonalite to diorite plutons and sills, and then cool, accompanied by a drop in pressure, through the conditions of formation of the andalusitebearing veins. This model seems less likely for two reasons. First, pelitic assemblages typically contain sillimanite + biotite + orthoclase indicating regional temperatures above at least $650^{\circ} \mathrm{C}$ occur virtually everywhere in the region of the Central Gneiss Complex shown in Figure 2. Second, to the west of Work Channel lineament (Locality 1, Figure 2), kyanite-bearing rocks were metamorphosed at pressures above 9 kbar [Crawford et al., 1979] (Figure 4), indicating that at least some rocks presently exposed in the Coast Plutonic Complex were once at the depths proposed in the uplift and cooling model.

\section{Discussion}

At the present stage of our investigation, we can piece together the following sequence of events across, and separately on each side, of the Work Channe1 lineament (Table 1).

1. The earliest recognizable post depositional event ( DW-1) produced open to overturned folds with fold axes trending approximately $20^{\circ}$ ESE. This event is recognized only west of the Work Channel lineament.

2. Following DW-1, the rocks were heated along essentially a 'normal' geotherm of about $25^{\circ} \mathrm{c} / \mathrm{km}$. This geotherm is documented on the west and may be extended to the eastern terrane to explain the relict high pressure assemblages. Thus, the preuplift metamorphic conditions deduced on the east side ( $10 \mathrm{kbar}, 800^{\circ} \mathrm{C}$; Figure 6) could be the up-grade continuation of the metamorphic gradient identified on the west side of the lineament. The continuity of the metamorphic gradient acrose the terrane boundaries implies that these terranes were probably contiguous by at least the time of metamorphigm in the west, which we conclude was in the Jurassic.

The main deformational event on the west (DW-2) coincided with this regional metamorphism.

TABLE 1. Chronology and Correlation of Deformational and Thermal Eventa

Unknown

$181 \mathrm{Ma}$

$85 \mathrm{Ma}$

$60 \mathrm{Ma}$

41-51 Ma
DW-1

intrusion of Ecstall pluton during $D W-2$ and during metamorphi am on $\sim 25^{\circ} \mathrm{C} / \mathrm{km}$ gradient

uplifted and cooled; K-Ar biotite ages not recognized

$\mathrm{DE}-1(?)$; high preasure and temperature metamorphiem(?); (discordant $\mathrm{Pb}-\mathrm{U}$ dates range from 108 to $171 \mathrm{Ma}$ )

remains at depth; oldest concordant $\mathrm{Pb}-\mathrm{U}$ date

emplacement of Quottoon and Kasiks Plutons; uplift starts

uplift in progress at $2 \mathrm{~mm} / \mathrm{yr}$; $\mathrm{DE}-2$, most intense near shear zones toward 1 ineament and development of mylonite at lineament

reheated from east (?); $D W-3$, 
It cannot be determined if $\mathrm{DE}-1$ coincided with the high pressure metamorphic event in the eastern terrane which is represented only by the relic as semblages. DE-1 certainly occurred prior to the later low pressure metamorphism in the eastern terrane which was contemporaneous with $\mathrm{DE}-2$. The evidence is consistent with $\mathrm{DW}-2$ being contemporaneous with $\mathrm{DE}-1$, but lack of continuity of mappable structures across the lineament and Quottoon Pluton prevents positive correlation of these two deformations.

On the west side, deformation in progress at peak metamorphic conditions resulted in overthrusting of hotter, deeper rocks westward over cooler, shallower rocks and the emplacement of the Ecstall pluton and related sills. Deformation and crustal thickening due to eastward subduction of a lithospheric plate is consistent with the data, although, in detail, the direction of transport could have varied considerably. This event probably terminated prior to the oldest biotite K-Ar cooling dates on plutons of the western terrane at $885 \mathrm{Ma}$ if we accept the model of Smith et al. [1979] that the progresgively younger dates toward the Work Channel lineament resulted from heating from the east. If the uplift were hinged, however, the eastern edge of the western terrane continued to be uplifted after this time. The rocks presently exposed in the eastern terrane, in either case, must have remained at depth. During uplift of the western terrane, the structural break between the eastern and western terranes was established.

3. The melts which later became the Quottoon and Kasiks plutons probably were generated just prior to the uplift of the eastern terrane which, according to the model (Figure 6) [Hollister, 1982] began at about $60 \mathrm{Ma}$ and terminated at about $45 \mathrm{Ma}$. The zircon ages were set at $\sim 58-60$ $\mathrm{Ma}$, and the $\mathrm{Rb}-\mathrm{Sr}$ whole rock date at $\backsim 51 \mathrm{Ma}$ was set as the plutons were uplifted and cooled. Alternatively, these plutons could have been generated contemporaneously with the events described in event 2, but they would have had to have remained at the deep level as substantially molten material for $50-60 \mathrm{Ma}$ or at least hot enough that the zircon ages were not set.

4. Uplift of the eastern terrane occurred between 60 and $45 \mathrm{Ma}$, with the western boundary of the uplift marked by the Work Channel 1 ineament. This uplift resulted in the DW-3 deformation observed in the western terrane and the near vertical lineations in the mylonites along Work Channel and may be correlative with $\mathrm{DE}-2$ in the eastern terrane. The eastern block remained hot during the uplift, and the low pressure met amorphism of the eastern terrane occurred as the rocks were being uplifted. This could account for reheating of the western terrane at this time, as postulated by Smith et al. [1979], and reheating of the Ecstall Pluton, as suggested by Harrison et al. [1979].

\section{Nature of Work Channel Lineament}

The Work Channel Lineament presently separates high pressure kyanite-grade rocks metamorphosed near 9-10 kbar on the west side from sillimanitecordierite gneisses on the east side which formed at about 5 kbar but contain relics of high pressure metamorphic assemblages. The rocks to the east were rapidly uplifted during the Eocene while still at or near peak metamorphic temperatures, whereas those to the west were uplifted and cooled by the Cretaceous. The different uplift histories across the 1 ineament have obscured the relation of the eastern to the western terrane during the Mesozoic.

A model for the development of the metamorphism and the structures in the area begins with a Jurassic ( $>180 \mathrm{Ma})$ crustal thickening. This generated the higher grade kyanite schists at depths of $s 25 \mathrm{~km}$. In the western terrane, juxtaposition of three distinct lithologic packets along easterly dipping moderate angle $\left(30^{\circ}-60^{\circ}\right)$ thrusts and shear zones suggests subsequent telescoping of the section with higher grade rocks emplaced over the more westerly lower grade ones. The metamorphic rocks west of the lineament, particularly the higher grade gneisses, represent parts of a stratigraphic section which may continue into the core zone of the Coast Plutonic Complex east of the 1 ineament.

The crustal thickening in the Jurassic may have been the result of subduction. In this case, the depth to the Benioff zone under Tsimpsean Peninsula and the area around Ketchikan must have been sufficient to generate the plutons which intrude the metasedimentary and metavo 1canic sequence west of the 1 ineament in this area and in southeast Alaska. This interpretation is similar to that proposed by Godwin [1975] for the same area. The Ecstall and related plutons and chemically similar dikes emplaced during the Jurassic may have helped lubricate thrust zones which emplaced deeper, hotter rocks over less metamor phosed units. After subduction ceased, the western rocks were uplifted relative to the eastern terrane along a fault which later became the Work Channel lineament; this uplift must have terminated by mid to upper Cretaceous. The fault along which the uplift occurred may coincide with the location of an older thrugt or a transcurrent fault associated with the Jurassic event.

During the Eocene, a second thermal event beginning at $\backsim 60 \mathrm{Ma}$, represented by intrusion of the Quottoon and Kasiks plutons, was closely followed by uplift of the eastern terrane with reactivation, as a fault, of the Work Channel lineament.

A significant amount of east-over-west thrusting and/or transcurrent motion along the Work Channel 1 ineament during the Jurassic and Cretaceous cannot be excluded. Structural evidence related to Eocene and subsequent events suggest that final motion along the lineament was dominantly vertical. Similarities of the early metamorphism and some structural elements in the eastern terrane to those in the west permit the inference that the two terranes were al so juxtaposed at the time of metamorphism of the western terrane, which we deduce to have been contemporaneous with the crystallization of the Ecstall Pluton during the Jurassic $(181 \mathrm{Ma})$. Thus we tentatively conclude that the events recorded in this part of British Col umbia reflect a major crustal thickening and suturing event in the Jurassic followed by uplift of the western terrane in the Cretaceous and of the eastern terrane in the Eocene. 
Acknowledgments. This study was supported by NSF grants EAR77-14921 and EAR81-00398 to Crawford and DES75-03259 and EAR80-07454 to Hollister. Logistic support for our field work was provided in part by the Geological Survey of Canada (GSC). We al so both express our gratitude to the Vancouver office of the GSC for hosting us during our sabbatical leaves (1980, LSH; 1981 , MLC) when we did much of the synthesis of field work which forms the basis of the present paper. We are grateful for the aid of many people in facilitating our field work: special thanks are due Ed Wampler (ESSO Marine Services, Ltd.) and Dave Newnan (Okanogan Helicopter, Ltd.) for exceptional logistic support and the many students at Bryn Mawr and Princeton who have aided our field work. We also thank the organizers of the 1979 GSA Penrose Conference on displaced terranes for providing the for um for us to begin to organize our thoughts and data into the regional context. The manuscript has benefitted considerably by reviews from Dave Brew and Jeff Warner and comments on the manuscript by $R$. $L$. Armstrong, J. Arth, F. Barker, and G. Wood sworth.

\section{References}

Albarède, F., Thermal models of post-tectonic decompression as exemplified by the Haut-Allier granulites (Massif Central, France), Bull. Soc. Geo1. Fr., 18, 1023-1032, 1976.

Armatrong, R. L., and D. Runkle, Rb-Sr geochronometry of the Ecstal1, Ritkiata, and Quottoon plutons and their country rocks, Prince Rupert region, Coast Plutonic Complex, British Columbia, Can. J. Earth Sci., 16, 387-399, 1979 .

Berg, H. C., D. L. Jones, and P. J. Coney, Map showing the pre-Cenozoic tectonic-stratigraphic terranes of southeastern Alaska and adjacent areas, 5, U.S, Geol. Surv. Open File Rep., 78-1055, 1978 .

Brew, D. A., and A. B. Ford, Megalineament in southeastern Alaska marks southwest edge of Coast Range batholithic complex, Can. J. Earth Sci., 15, 1763-1772, 1978.

Crawford, M. L., Fluid inclusions in metamorphic rocks--Low and medium grade, in MAC Short Course in Fluid Inclusions Applications to Petrology, edited by L.S. Hollister and M.L. Crawford, pp. 157-181, Mineralogical Association of Canada, Toronto, 1981.

Crawford, M. L., D. W. Kraus, and L. S. Hollister, Petrologic and fluid inclusion study of calc-silicate rocks, Prince Rupert, British Columbia, Am. J. Sci., 279, 1135-1159, 1979.

Ganguly, J., Chloritoid stability and related paragenesis: Theory, experiments and applications, Am. J. Sci., 267, 277-298, 1969.

Ghent, E. D., D. B. Robbins and M. Z. Stout, Geothermometry, geobarometry, and fluid compositions of metamorphosed calc-silicates and pelites, Mica Creek, British Columbia, Am. Minera1., 64, 874-885, 1979.

Godwin, C. I., Imbricate subduction zones and their relationships with Upper Cretaceous to Tertiary porphyry deposits in the Canadian Cordillera, Can. J. Earth Sci., 12, 1362-1378, 1975.
Harrison, T. M., R. L. Armstrong, C. W. Naeser, and J. E. Harakal, Geochronology and thermal history of the Coast Plutonic Complex, near Prince Rupert, British Columbia, Can. J. Earth Sci., 16, 400-410, 1979 .

Holdaway, M. J., and S. M. Lee, Fe-Mg cordierite stability in high-grade pelitic rocks based on experimental, theoretical, and natural observations, Contr. Mineral. Petrol., 68, 195-198, 1977.

Hollister, L. S., The reaction forming cordierite from garnet, the Khtada Lake metamorphic complex, British Columbia, Can. Mineral., 15, 217-229, 1977.

Hollister, L. S., Metamorphism and crustal displacements: New insights, Episodes, 1979, 3-8, 1979.

Hollister, L. S., Metamorphic evidence for rapid ( $2 \mathrm{~mm} / \mathrm{yr}$.) uplift of a portion of the Central Gneiss Complex, Coast Mountains, British Columbia, Can. Mineral., 20, in press, 1982.

Holl ister, L. S. and M. Sherwood, Metamorphic evidence for rapid uplift, Coast Ranges, Britioh Columbia, Canada, Int. Geol. Cong. 26th Abstr., 1, 51, 1980.

Hollister, L. S., R. C. Burruss, D. L. Henry, and E. M. Hendel, Physical conditions during uplift of metamorphic terranes as recorded by fluid inclusions, Bul1. Mineral., 102, 555-561, 1979.

Hutchison, W. W., Prince Rupert and Skeena Map-Area, British Columbia, Can. Geol. Surv. Pap. 66-33, 27 Pp., 1967.

Hutchison, W. W., Metamorphic framework and plutonic styles in the Prince Rupert region of the Central Coast Mountains, British Columbia, Can. J. Earth Sci., 7, 376-405, 1970.

Hutchison, W. W., Prince Rupert-Skeena Geologic Map, Geo1. Surv. Can. Map, 1472A, 1971.

Kenah, C., Mechanism and physical conditions of emplacement of the Quottoon Pluton, British Columbia, Ph.D. thesis, 184 Pp., Princeton Univ., Princeton, N.J., 1979.

Lappin, A. R., and L. S. Hollister, Partial melting in the Central Geiss Complex near Prince Rupert, British Columbia, Am. J. Sci., 280, 518-545, 1980.

Liou, J. G., Synthesis and stability relationships of epidote, $\mathrm{Ca}_{2} \mathrm{Al}_{2} \mathrm{FeSi}_{3} \mathrm{O}_{12}(\mathrm{OH}), \mathrm{J}$. Petrol., 14, 381-413, 1973 . $312,18, \bar{O}{ }^{16} \mathrm{O}$ and $\mathrm{D} / \mathrm{H}$ studies along a $500 \mathrm{~km}$ traverse across the Coast Range batholith and its country rocks, central British Columbia, Can. J. Earth Sci., 13, 1574-1536, 1976.

Naney, M. T., Phase equilibria and crystallization in iron- and magnesium-bearing granitic systems, Ph.D. thesis, Stanford Univ., Stanford, Calif., 1977.

Parrish, R., Fission-track estimate of paleo-heat flow, Coast Mountains of British Columbia (abstract), EOS Trans., 61, 1131, 1980.

Perkins, D., III, and R. C. Newton, Charnockite geobarometers based on coexisting garnetpyroxene-plagioclase-quartz, Nature, 292, $144-146,1981$.

Perkins, D., III, E. F. Westrum, Jr., and E. J. Essene, The thermodynamic properties and phase relations of some minerals in the system $\mathrm{CaO}-\mathrm{Al}_{2} \mathrm{O}_{3}-\mathrm{SiO}_{2}-\mathrm{H}_{2} \mathrm{O}$, Geochim. Cosmochim. Acta, 44, $61 \stackrel{2}{2} 84,1980.2$ 
Selverstone, J., and L. S. Hollister, Cordieritebearing granulites from the Coast Ranges, British Columbia: P-T conditions of metamorphism, Can. Mineral., 18, 119-129, 1980.

Smith, J. G., and M. F. Diggles, Potassium-argon determinations in the Retchikan and Prince Rupert quadrangles, southeastern Alaska, U.S. Geol. Surv. Open File Rep., 78-73N, 1981.

Smith, J. G., T. W. Stern, and J. G. Arth, Isotopic ages indicate multiple episodes of plutonism and metamorphism in the Coast Mountains near Ketchikan, Alaska, Geol. Soc. Am. Abstr. Programs, 11, 519, 1979.

Wyllie, P. J., Crustal anatexis: An experimental review, Tectonophysics, 43, 41-71, 1977.

(Received June 18, 1981; revised November 11,1981 ; accepted December 14, 1981.) 